\title{
Design of Inhibitors for Nucleoside Hydrolase from Leishmania donovani using Molecular Dynamics Studies
}

\author{
Tanos C. C. França, ${ }^{a}$ Maria do Ramo M. Rocha, ${ }^{a}$ Bruno M. Reboredo, ${ }^{a}$ Magdalena N. Rennó, ${ }^{a}$ \\ Luzineide W. Tinoco ${ }^{b}$ and José D. Figueroa-Villar*a
}

\author{
${ }^{a}$ Seção de Engenharia Química, Instituto Militar de Engenharia, Praça General Tibúrcio, 80, Urca, 22290-270 \\ Rio de Janeiro-RJ, Brazil \\ ${ }^{b}$ Núcleo de Pesquisas de Produtos Naturais (NPPN), Universidade Federal do Rio de Janeiro, \\ Av. Brigadeiro Trompowski, s/n, Ilha do Fundão, 21941-590 Rio de Janeiro-RJ, Brazil
}

Neste trabalho é proposto o primeiro modelo por homologia para a nucleosídeo hidrolase de Leishmania donovani construído a partir das estruturas das nucleosídeo hidrolases de Crithidia fasciculata e de Leishmania major. Usando as informações de interação entre o inibidor p-aminofeniliminoribitol e a nucleosídeo hidrolase de Crithidia fasciculata foram planejados dois novos potenciais inibidores, os quais apresentam novas interações com alguns resíduos da bolsa hidrofóbica do sítio ativo do modelo. Simulações por dinâmica molecular dos protótipos ancorados nos sítios ativos do modelo e das enzimas usadas como moldes, mostraram que, diferente do $p$-aminofeniliminoribitol, eles permaneceram ancorados nos sítios ativos das três enzimas ao longo de toda a dinâmica, interagindo fortemente com os aminoácidos da bolsa hidrofóbica.

In this work we propose the first homology model for nucleoside hydrolase from Leishmania donovani, built based on the crystallographic structures of Crithidia fasciculata and Leishmania major nucleoside hydrolases. We used the interaction information from the crystallographic model of the enzyme of $C$. fasciculata in complex with the inhibitor $p$-aminophenyliminoribitol, to design two new potential inhibitors, which present new interactions with some residues of the hydrophobic pocket of the model active site. Molecular dynamics simulations of the prototypes inside the active sites of the model and the template enzymes showed that, differently from $p$-aminophenyliminoribitol, they remained tightly bound inside the active sites, interacting strongly with the amino acids from the hydrophobic pocket.

Keywords: visceral leishmaniasis, Leishmania donovani, metalloproteins, homology modeling, molecular dynamics

\section{Introduction}

According to the World Health Organization (WHO), leishmaniasis is a threat for 350 million people in 88 countries, where 72 of those are developing countries. WHO also estimates that 12 million people in the world are infected and 2 million new cases appear annually, despite the official report of only about 600,000 new cases every year. ${ }^{1}$ It is clear that leishmaniasis is one of the most important parasitic diseases, which is caused by protozoan of the

\footnotetext{
*e-mail: figueroa@ime.eb.br
}

Leishmania genus. This disease affects humans in four different forms with a broad range of clinical manifestations: visceral, mucocutaneous, cutaneous and diffuse cutaneous leishmaniasis. ${ }^{1-4}$ Visceral leishmaniasis, also known as "kala-azar", is considered the most dangerous form of this disease, being fatal in $100 \%$ of the untreated cases ${ }^{1}$ and is caused by the L. donovani complex. ${ }^{4}$

The search for prevention against leishmaniasis infection includes vaccines with weakened and genetically modified strains of the parasite and recombinant antigens ${ }^{5}$ or its encoding DNA. ${ }^{6}$ The only preventive treatment for leishmaniasis available today is the canine vaccine 
Leishmune ${ }^{\circledR} .^{7}$ An efficient human vaccine is not available yet. Accordingly, the most effective way to combat leishmaniasis still is the use of chemotherapy.

The chemotherapy against leishmaniasis is still based on the use of the very toxic pentavalent antimonium compounds and pentamidine. Using those compounds, the treatment of patients with leishmaniasis may last up to several weeks, thus maximizing the occurrence of undesirable collateral effects like abdominal pain and renal and hepatic toxicity. Moreover, there is evidence of the emergence of parasites which are resistant to the commonly used antimony drugs. ${ }^{4,8}$ It is therefore quite clear that there is a great need to discover new antileishmanial compounds and new targets for chemotherapy. ${ }^{9-11}$

Parasitic nucleoside hydrolases $(\mathrm{NH})$ have been extensively studied as potential targets for chemotherapy. ${ }^{12-18}$ These enzymes are widely distributed in nature and have already been found in bacteria, ${ }^{19,20}$ yeast, ${ }^{21}$ protozoa $^{16,22}$ and insects. ${ }^{23}$ Their encoding genes are present in plants, amphibians and fish but, surprisingly, no $\mathrm{NH}$ activity or their encoding genes have been detected in mammals until the present moment. ${ }^{18}$ This fact turns $\mathrm{NH}$ into ideal targets for selective chemotherapy for parasitic and bacterial infections.

The NH, or nucleoside N-ribohidrolases, present in the genus Leishmania, are part of a super family of metalloproteins structurally related with an original topology of $\beta$-sheets. ${ }^{24,25}$ All NH studied to date are homodimers or homotetramers and present great similarity in the amino acid sequences of the active site, thus indicating that they are closely related in structure and catalytic mechanism. Accordingly, it is quite possible that the inhibitors for a $\mathrm{NH}$ from one parasite could be active for a wide range of species. ${ }^{14-16}$

The analysis of the crystallographic structure of $\mathrm{NH}$ from Crithidia fasciculata complexed with $p$-aminophenyliminoribitol (pAPIR) shows that each NH monomer is functional and contains a narrow and deep active site with a strongly bound $\mathrm{Ca}^{2+}$ ion. ${ }^{18,26-28}$ This cation is octacoordinated by a net of interactions involving the $\mathrm{O}$ atoms of the side chains of residues Asp10, Asp15, Asp242, the carbonyl oxygen of the main chain of Thr126, and three water molecules. In the enzyme-substrate complex, two of the water molecules are replaced by the 2' and 3' hydroxyl groups of the substrate ribose. The specificity of $\mathrm{NH}$ for the ribose fraction is established by a net of conserved interactions involving the 2', 3' and 5' hydroxyl groups of the sugar, the conserved residues Asp14, Asn160, Glu166, Asn168 and Asp242 and the $\mathrm{Ca}^{2+}$ ion. ${ }^{18}$

Nonspecific NH catalyze the hydrolysis of purine and pirimidine nucleosides, as well as the hydrolysis of p-nitrophenyl- $\beta$-D-ribofuranoside. In contrast, specific NH prefer purine nucleosides, being poor catalysts for pirimidine nucleosides and $p$-nitrophenyl- $\beta$-D-ribofuranoside hydrolysis. ${ }^{29-32}$

The monomeric NH from L. donovani ( $\mathrm{LdNH})$ presents 314 residues and its three-dimensional structure has not been experimentally elucidated yet. Fortunately it presents a quite significant homology with the nonspecific Leishmania major nucleoside hydrolase ( $\mathrm{LmNH}), 95 \%$ of sequential identity, and Crithidia fasciculata nucleoside hydrolase $(\mathrm{CfNH}), 80 \%$ of sequential identity, suggesting that this enzyme is also nonspecific, as proposed by Cui et $a l .{ }^{16}$ based on enzymatic assays. The high conservation of the NH sequences among the Trypanosomatidae species suggests that this enzyme is fundamental for the purines and pirimidines salvage in these species. Considering that one of the metabolic factors that differentiate protozoan parasites from mammals is the lack of de novo biosynthesis of purines and pirimidines, these parasites depend exclusively of purines and pirimidines from the host to survive.

In this work we report the first multiple alignment homology model for LdNH, built based on the crystallographic structures of CfNH and LmNH. Also, analysis of pAPIR, a known CfNH inhibitor, ${ }^{33}$ docked inside the active site of $\mathrm{CfNH}$, pointed to six residues on the hydrophobic pocket of the active site that are close enough to interact with eventual pAPIR derivatives with substitutions in their aromatic base portion. The analyses of the potential interactions with such residues lead to the proposition of two new potential $\mathrm{NH}$ inhibitors. Dynamics simulations of $2 \mathrm{~ns}$ of pAPIR and the proposed inhibitors inside the active sites of $\mathrm{LdNH}, \mathrm{LmNH}$ and $\mathrm{CfNH}$, showed that those compounds, differently from pAPIR, remained tightly bound inside the active sites of the three enzymes during the whole simulation, interacting strongly with those residues of the hydrophobic pocket that are not able to interact with pAPIR.

\section{Methods}

In the search for good templates, all the amino acid sequences of NH from protozoa available in the Protein Data Bank (PDB) ${ }^{34}$ were investigated. Among the NH structures found, the only ones possessing more than $35 \%$ of sequence identity with $\mathrm{LdNH}$ were the enzymes from $L$. major (PDB entry 1EZR; resolution $=2.5 \AA$, R-value $=0.203)^{15}$ and $C$. fasciculata $(\mathrm{PDB}$ entry $2 \mathrm{MAS}$; resolution $=2.30 \AA$, R-value $=0.205) .{ }^{14}$ These sequences, after alignment with the LdNH sequence using the BLAST server, ${ }^{35,36}$ presented $95 \%$ and $80 \%$ of sequence identity, respectively.

The multiple alignment of the primary sequences of LdNH, LmNH and CfNH were manually refined in order 
to reproduce the alignment of the $\mathrm{LdNH}, \mathrm{LmNH}$ and $\mathrm{CfNH}$ sequences proposed by Cui et al. ${ }^{16}$ This refined alignment was then submitted to the SWISSMODEL server, ${ }^{37-39}$ in the optimize mode, in order to generate the final model of the monomeric apoenzyme.

After building the structure of the LdNH apoenzyme model, the following step was to build the enzyme $/ \mathrm{Ca}^{2+} /$ pAPIR complex by docking pAPIR, and $\mathrm{Ca}^{2+}$ into the enzyme active site. This task was accomplished by the superposition of the backbone of our model with the crystallographic structure of $\mathrm{CfNH}$ complexed with $\mathrm{Ca}^{2+}$ and pAPIR (PDB entry 2MAS). The coordinates of $\mathrm{Ca}^{2+}$ and pAPIR were, then, copied into the model. The atomic partial charges of $\mathrm{Ca}^{2+}$ and pAPIR were previously calculated at the Hartree Fock level with the $6-31 G^{*}$ basis set using the CHELPG approach of the Gaussian98 package, ${ }^{40}$ and their topological files, which are compatible with the format of the GROMACS 3.2 package ${ }^{41,42}$ databank, were generated at the Dundee PRODRG server. ${ }^{43}$ The holoenzyme obtained by this procedure, which volume is about $300 \mathrm{~nm}^{3}$, was set into a cubic box of about $722.86 \mathrm{~nm}^{3}(\mathrm{~nm}=$ nanometer $)$ containing 21,332 water molecules and minimized with the GROMOS96 force field ${ }^{44}$ implemented in the GROMACS 3.2 package. ${ }^{41,42}$ The minimization steps were carried out, firstly, using the steepest descent algorithm until reaching an energy gradient of $100 \mathrm{kcal} \mathrm{mol}^{-1} \mathrm{~nm}^{-1}$ and further with the conjugate gradients algorithm until reaching the energy gradient of $20 \mathrm{kcal} \mathrm{mol}^{-1} \mathrm{~nm}^{-1}$.

In order to check the quality of our model, it was submitted to validation analysis at the Biotech Validation Suite for Protein Structures. ${ }^{45}$ There were performed the atomic volume analysis by PROVE, ${ }^{46}$ the full geometric analysis by PROCHECK $^{47}$ and all the WHAT IF $^{48}$ checks available on the site. Furthermore, the model was also submitted to the Verify $3 \mathrm{D}^{49,50}$ structure evaluation server ${ }^{51}$ in order to check for the chemical environment of each residue and had its Z-scores calculated using the software PROSA 2003.52

The two proposed compounds as potential $\mathrm{NH}$ inhibitors were built using the Gaussian View software from the Gaussian 98 package, ${ }^{40}$ based on the structure of pAPIR as template and using the potential interactions with the hydrophobic pocket of the active site as a guide. In the same way as for $\mathrm{Ca}^{2+}$ and pAPIR, the potential inhibitors had their atomic partial charges calculated at the Hartree Fock level with the $6-31 \mathrm{G}^{*}$ basis set using the CHELPG approach of the Gaussian98 package, ${ }^{40}$ and their topological files generated at the Dundee PRODRG server. ${ }^{43}$ The insertions of the proposed inhibitors into the $\mathrm{LdNH}, \mathrm{LmNH}$ and $\mathrm{CfNH}$ active sites were performed by superposition to the pAPIR in the same conformation as reported in the literature. ${ }^{33}$ Furthermore, LdNH and the crystallographic structures of
LmNH and $\mathrm{CfNH}$, with $\mathrm{Ca}^{2+}$ and each proposed compound docked into their active sites, were submitted to rounds of energy minimization following the same procedure described to the $\mathrm{LdNH} / \mathrm{Ca}^{2+} / \mathrm{pAPIR}$ complex.

The molecular dynamics (MD) steps were carried out according to the following procedure: First, a $50 \mathrm{ps}$ of MD at $300 \mathrm{~K}$ in the water molecules inside the box in order to allow for the equilibration of the solvent around the protein residues. In this simulation, all protein atoms had their positions restrained. Then, it was carried out a full MD simulation of 2,000 ps at $300 \mathrm{~K}$ with no restrictions, using 1 fs of integration time and a cut-off of $14 \AA$ (angstroms) for long-range interactions.

Because these proteins have only a residual net charge, which was balanced by contra-ions for these simulations, it was possible to use the direct cut-off for long range interactions without smoothening functions. The effects of the electrostatic potential truncation are minor at $14 \AA$, and the cut-off procedure makes the calculations faster than other methods. Considering that the protein monomer and the water molecules inside the simulation box are composed by about 130,000 atoms, this method can save significant computational time.

As a whole, 1,000 conformations were stored during each simulation. In this step the pair lists were updated every 500 time steps and all the Lys and Arg residues were positively charged while the Glu and Asp residues were negatively charged.

Also, in order to obtain a neutral net charge for all the systems, the charges were neutralized by the addition of $\mathrm{Na}^{+}$ions. The program calculates the electrostatic potential to find best positions for ion insertion by replacing water molecules that are at least at $3.50 \AA$ from the protein surface. There were employed Periodic Boundary Conditions (PBC) and the water model used was the Simple Point Charge water (SPC), the default solvent of the GROMACS 3.2 package. ${ }^{41,42}$

The hardware resources used in this work were a PC AMD Atlhon 2,000 MHz and a cluster of computers composed by a PC Pentium IV 2.4 and four PC Pentium 2,600 MHz.

\section{Results and Discussion}

\section{Homology modeling}

Even considering the sequence similarity of $95 \%$ and $80 \%$ between the target and the two template proteins, it was important to obtain a homology model of the target protein, because the aim of this work was the design of new potential inhibitors. The most desirable model for this type 
of work is the crystallographic structure of the protein with a known inhibitor inside the active site. In the present case, the use of very similar crystallographic templates guarantee the obtainment of a very good quality model, as it is necessary for a precise description of the active site.

One of the most important steps in homology modeling is the definition of the correct sequence alignment between the target and the template proteins. Figure 1 shows our final alignment, which was submitted to the SWISSMODEL server $^{37-39}$ in order to build the initial model of LdNH. This alignment was obtained after manual adjustments of the initial alignment obtained from the BLAST server ${ }^{35,36}$ in order to reproduce the alignment of $\mathrm{LdNH}, \mathrm{LmNH}$ and CfNH sequences proposed by Cui et al. ${ }^{16}$

The Ramachandran plot $^{53}$ of the model shows more than $98 \%$ of the amino acid residues in the favorable regions of the plot for the whole enzyme, and $100 \%$ for the active site residues.

The backbones of the modeled monomer of LdNH and the templates used in the multiple alignment were superimposed, using SPDBViewer, ${ }^{36}$ in order to calculate the RMSD values and to check the structural compatibility of the model with the templates (see Figure 2). As it was expected due to the great sequence similarity between the target and the template enzymes, the RMSD values obtained were of $0.1 \AA$ and $0.08 \AA$ for $\mathrm{CfNH}$ and $\mathrm{LmNH}$ respectively, thus confirming that the templates are satisfactory for the homology modeling process. The superposition of the backbones shows that the general fold of LdNH is almost identical to $\mathrm{LmNH}$ and differs from CfNH only at the external loops L1 and L2, which are located at the entrance of the enzymes active sites. As can be seen in Figure 2, those loops in $\mathrm{CfNH}$ are closer to each other, turning the entrance of this enzyme active site narrowed than in LdNH and LmNH.

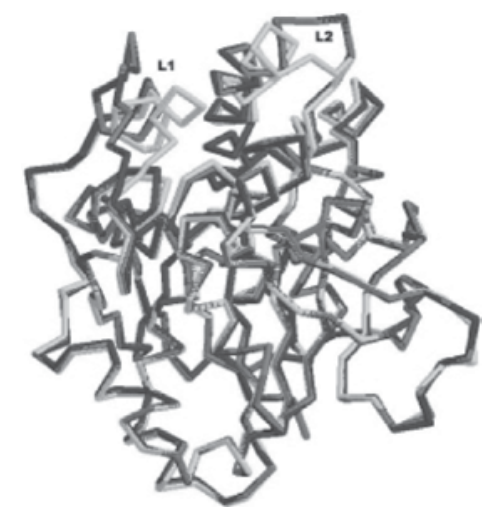

Figure 2. Superposition of the backbones of our model and the templates. Black: LmNH, Dark gray: LdNH and Ligth gray: CfNH.

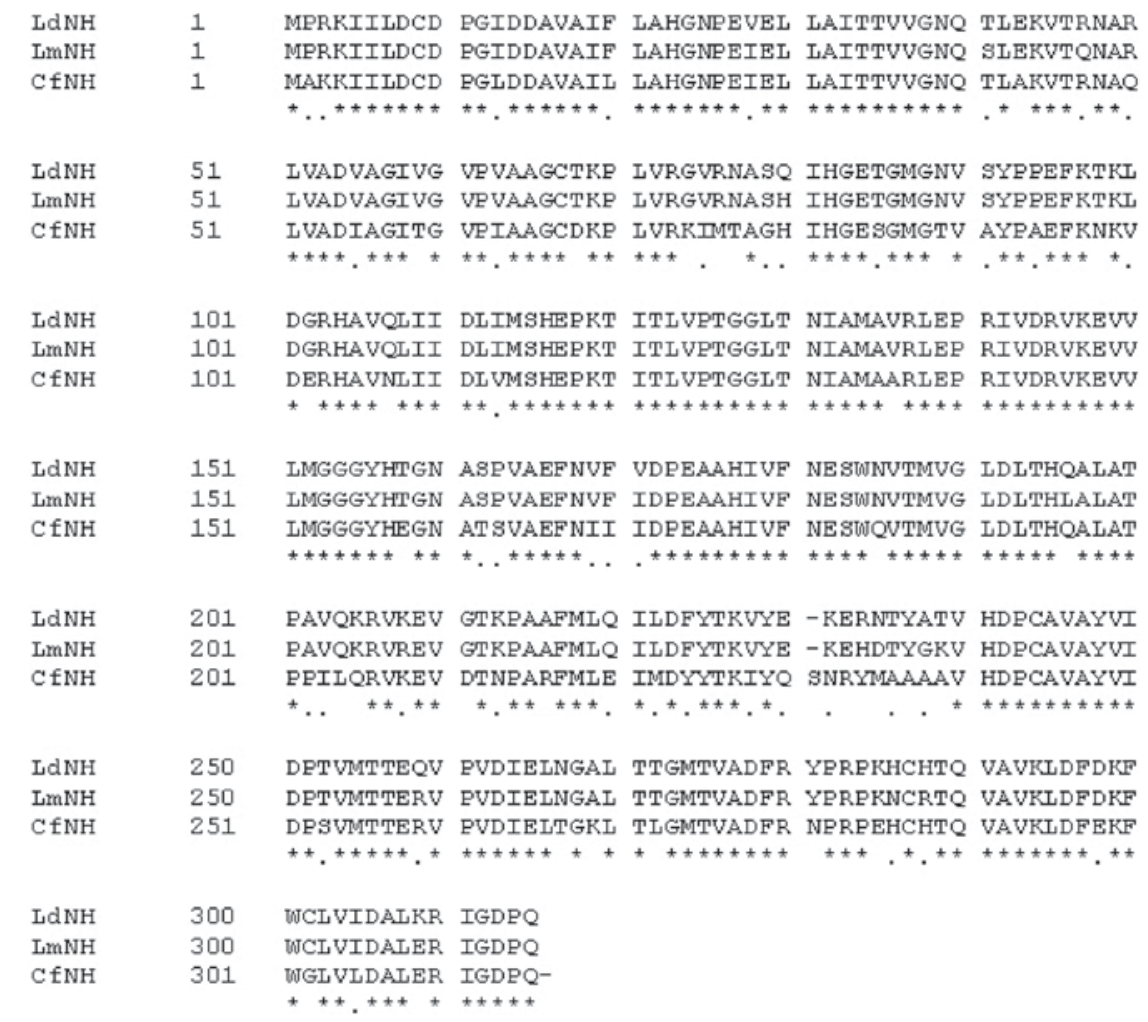

Figure 1. Alignment of LdNH amino acids sequence with the sequences of the Crystallographic structures of LmNH and CfNH available in PDB. 


\section{Validation of the model and active site determination}

Regarding the main chain properties of the modeled enzyme, the careful examination of the checking results performed at the Biotech Validation Suite for Protein Structures, ${ }^{45}$ did not show any considerable bad contacts, nor $\mathrm{C}_{\alpha}$ tetrahedron distortion nor buried unsatisfied $\mathrm{H}$-bond donors and acceptors. Moreover, the average G-factor (-1.04), was well inside the permitted values for homology models. ${ }^{47}$ The G-factor provides a measure of how "normal", or alternatively how "unusual", a given stereochemical property is. When applied to a given residue, a low G-factor indicates that the property corresponds to a low-probability conformation. For example, residues falling inside the disallowed regions of the Ramachandran plot will have a low (or very negative) G-factor.

Additionally, there were not found any distortions of the side chain torsion angles, the 3D-1D averaged score for each residue calculated by the Verify $3 \mathrm{D},{ }^{49,50}$ ranged among 0.08 and 0.69 and the Z-scores calculated using the software PROSA 2003, ${ }^{52}$ showed that $\mathrm{LdNH}$ and its templates are inside the range of a typical native structure.${ }^{54}$ Accordingly to these results, the model was considered satisfactory.

The active site determination in our model was accomplished based on its alignment to the templates. There were found degrees of sequence identity of $100 \%$ of the active site with $\mathrm{LmNH}$ and $98 \%$ with $\mathrm{CfNH}$. As it is the case for $\mathrm{LmNH}$, the active site of $\mathrm{LdNH}$ presents the residues: Asp10, Asp14, Asp15, Asn39, Ile81, His82, Thr126, Met152, Asn160, Glu166, Phe167, Asn168, Tyr225, Tyr229, Glu232, His241 and Asp242. In the active site of CfNH, however, Glu232 is replaced by Arg233. ${ }^{13,15,16,18}$

Superimposing the residues of the active sites from our model and the templates, it can be initially inferred, based on the alignment in Figure 1 and the picture of the active site from $\mathrm{CfNH}$ reported by Versées and Steyaert, ${ }^{18}$ that, in LdNH and LmNH, residues Asp10, Asp14, Asp15, Asn39, Thr126, Asn160, Glu166, Asn168 and Asp242, would be the ones that stabilize the binding of the ribose portion of the nucleosides, while the hydrophobic pocket of the nucleic base would be formed by residues Ile81, His82, Asn160, Phe167, Tyr225, Tyr229 and His241. Also, residues Asp10, Asp15, Thr126 and Asp242 would be the ones binding the $\mathrm{Ca}^{2+}$ ion. As it can be noticed in the superposition in Figure $3, \operatorname{Arg} 233$ and the residues of the hydrophobic pocket: Asn39, Ile81, His82, Tyr225 and Tyr229 in CfNH, do not superimpose well to their homologues in $\mathrm{LmNH}$ and LdNH. This happens because those residues are located at loops L1 and L2, which are the only elements of secondary structure of CfNH that do not fit well to LdNH and LmNH as already shown in Figure 2.

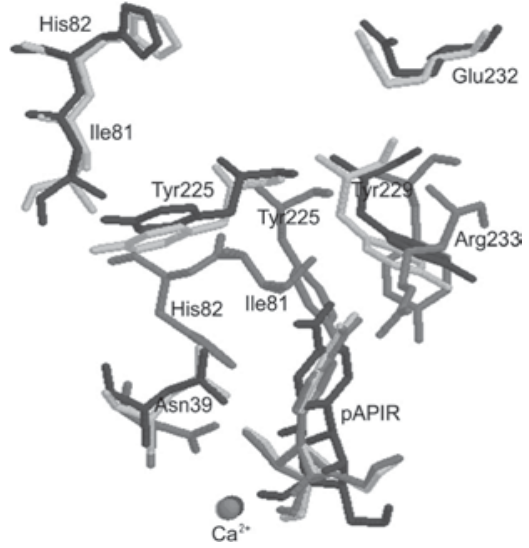

Figure 3. Superposition of some residues of the active sites hydrophobic pockets of our model and the templates Black: LmNH, Dark gray: $\mathrm{CfNH}$ and Ligth gray: $\mathrm{LdNH}$

Analysis of the potential interactions of pAPIR inside the CfNH active site and proposition of potential inhibitors

Analysis of Figure 4 shows that the pAPIR aromatic base portion is inserted into a pocket, defined mainly by the residues Asn39, His82, Asn160, Tyr225, Tyr229 and Arg233. However, the side chains of these residues are between 2.25 and $4.77 \AA$ from the pAPIR aromatic base atoms. Those distances seem too far to enable electrostatic interactions or the formation of $\mathrm{H}$ - bonds that would stabilize the base portion inside the active site. This inability to anchorage properly the aromatic base portion of pAPIR could be the main reason for the low inhibition of $\mathrm{NH}$ by pAPIR when compared to other inhibitors with substitutions on the aromatic base portion, as already described in literature. ${ }^{21}$ In fact, Miles et al..$^{55}$ have synthesized and evaluated the inhibitory activity of 20 pAPIR analogues against specific and non-specific NH. He showed that the most powerful inhibitors of $\mathrm{NH}$ are just the ones presenting substitutions at the aromatic base portion. We believe that this probably happens because these groups are able to interact with the hydrophobic pocket residues. The presence of the side chains of Asn39, His82, Asn160, Tyr225, Tyr229 and Glu232 (Arg233 in CfNH) in positions quite close to the aromatic base portion of the inhibitors represents a good opportunity to design new derivatives of pAPIR with substitutions in this part of the molecule. These compounds could be able to interact specifically with those residues, thus binding more tightly to the active site.

That analysis lead to the proposition of the structures of the two pAPIR derivatives as potential inhibitors of non-specific NH, which are shown in Figure 5. Compound 1 was proposed based on the substitution of the group $p$-amino phenyl of pAPIR by a quinoline ring substituted by an amino group at position 2 and an amino acid group 

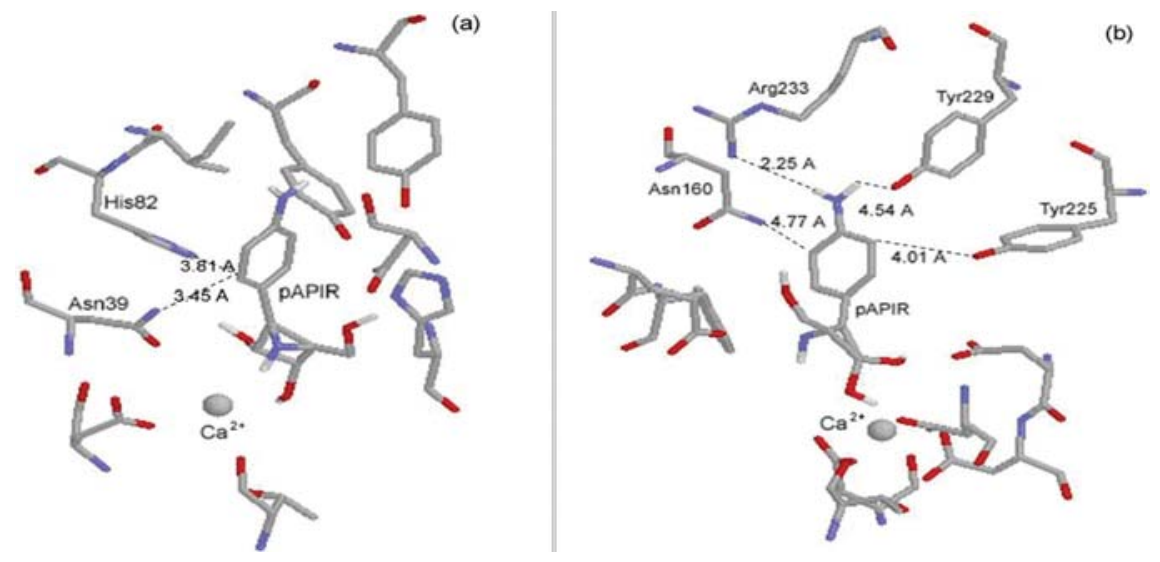

Figure 4. pAPIR inside the active site of $\mathrm{CfNH}$. (a) side view; (b) front view.

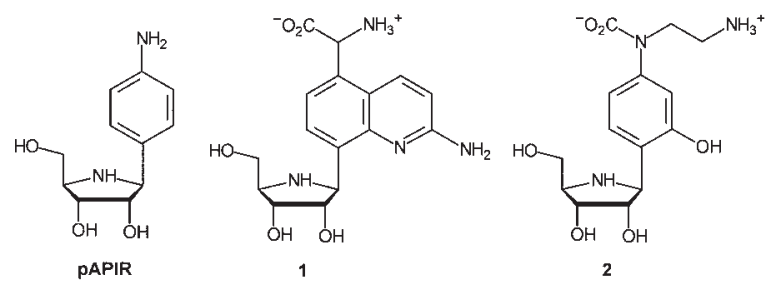

Figure 5. Proposed structures of two new potential inhibitors for non specific NHs.

(glycine) at position 5. This creates several possibilities of interactions with the polar groups (amine, amide or hydroxyl) of the side chains of residues Asn160, Tyr225, His82 and Asn39 as well as hydrophobic interactions like $\pi-\pi$ stacking and H-bonds with Tyr225 and Tyr229. In the proposed compound 2 we added to the aromatic amine of pAPIR, a carboxyl and an ethylamine groups with the goal of exploring possible interactions with the side chains of Asn160, Tyr229 and Glu232 (Arg233 in CfNH). Also, a meta hydroxyl group was placed at the aromatic ring in order to explore interactions with Asn39 and His82. The chemical environment around compounds 1 and 2 inside the $\mathrm{CfNH}$ hydrophobic pocket is shown in Figure 6.

\section{Molecular dynamics simulations}

In order to determine if the proposed inhibitors would interact with the active site of $\mathrm{LdNH}$ they were docked, together with the $\mathrm{Ca}^{2+}$ cation, inside the active sites of $\mathrm{LdNH}, \mathrm{LmNH}$ and $\mathrm{CfNH}$, affording six enzyme/ $\mathrm{Ca}^{2+} /$ inhibitor complexes. This docking was accomplished using as basis the intermolecular interactions present in the crystallographic structure of pAPIR bound with the active site of CfNH. Each complex was submitted to $50 \mathrm{ps}$ of position-restrained MD (PRMD)

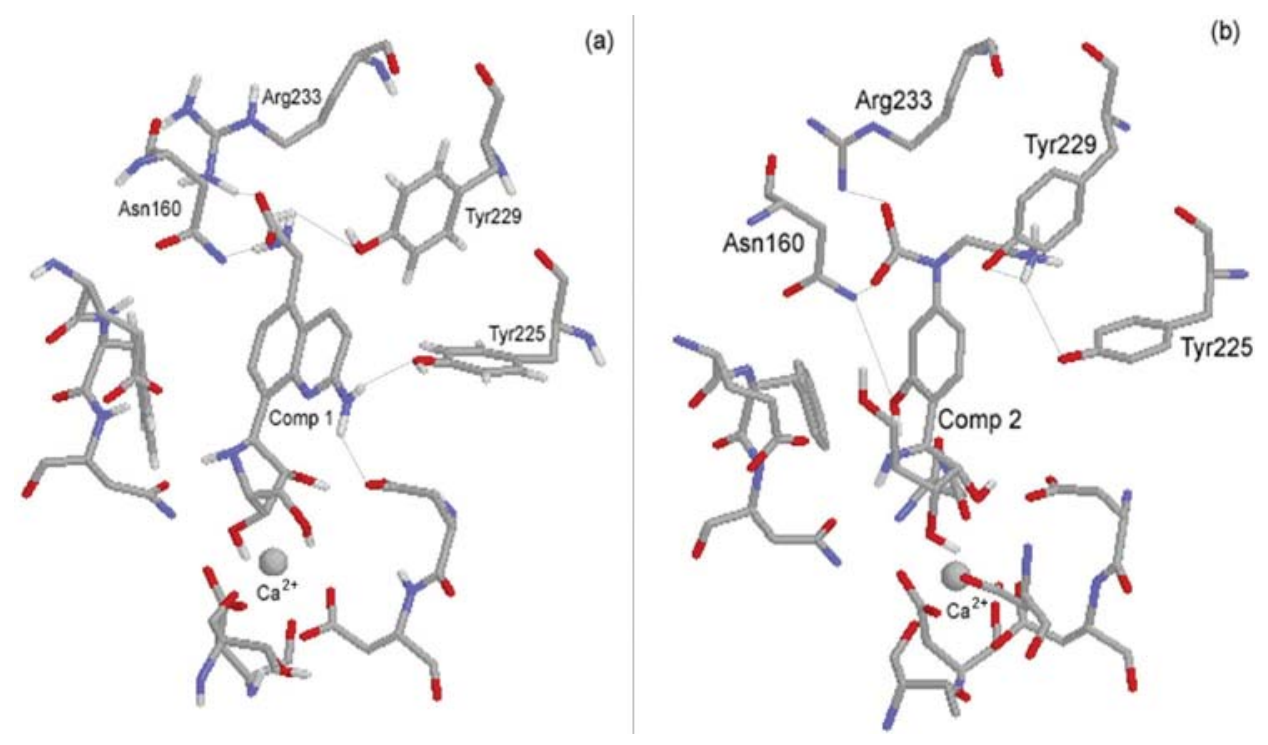

Figure 6. Chemical environment around compounds 1 (a) and 2 (b) inside the CfNH hydrophobic pocket. 
followed by 2,000 ps of MD simulations with no restriction, as described in the methods section.

There were carried out calculations of temporal RMSD on all the atoms in all the systems for 1,000 frames generated at each 2 ps of MD simulation. In this case the result is a unique general value for each enzyme monitored throughout the whole simulation time. Taking into account that the complexes could float inside the water box, each frame was adjusted to the former by the minimum squares method when calculating the standard deviation. In Figure 7, where the variation of the RMSD with time is monitored, it can be observed that the systems $\mathrm{NH} / \mathrm{Ca}^{2+} / \mathrm{Compound} 1$ equilibrate along the first few picoseconds of the MD simulation. This behavior was common to all $6 \mathrm{MD}$ simulations, with deviations never passing 0.1 $\mathrm{nm}$ after the first $100 \mathrm{ps}$ of simulation. We also observed that, for all simulations, the temporal RMSD of NH as apoenzymes practically fits the temporal RMSD of the complexes. Also, as expected, the ligands display a greater fluctuation than for the whole complexes but with a smaller RMSD, thus confirming the stability of the MD simulations.
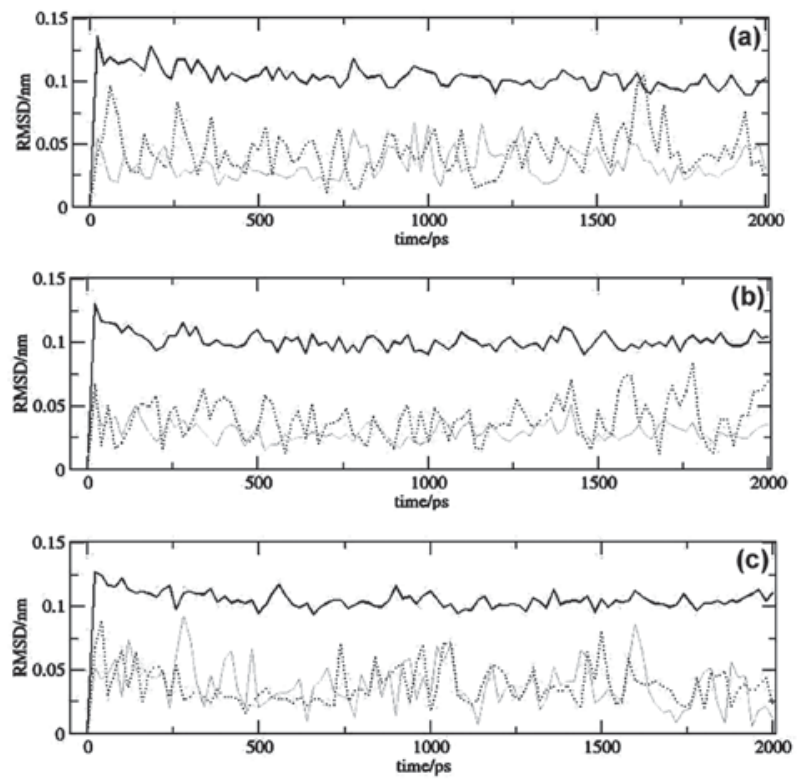

Figure 7. RMSD plots for the MD simulations. (a) $\mathrm{LdNH} / \mathrm{Ca}^{2+} / \mathrm{Com}-$ pound 1; (b) $\mathrm{LmNH} / \mathrm{Ca}^{2+} / \mathrm{Compound} 1$; (c) $\mathrm{CfNH} / \mathrm{Ca}^{2+} / \mathrm{Compound} 1$. Black line: enzyme and enzyme/inhibitor; Grey line: inhibitor; Dotted line: $\mathrm{Ca}^{2+}$ ion.

The spatial RMSD (RMSF) on each amino acid residue was also calculated in the time range of 100 to $2,000 \mathrm{ps}$, at each 1 ps, totalizing 1,900 frames. Figure 8 shows the plots of RMSF for the systems $\mathrm{NH} / \mathrm{Ca}^{2+} / \mathrm{Compound} 1$, with the total RMSF (peptide backbone plus side chains) in gray, the RMSF of the peptide backbone $(\mathrm{N}, \mathrm{C} \alpha, \mathrm{C})$ in black and the RMSF of the side chains in dotted lines. In Figure 9 are shown the qualitative illustrations in the tube representation of the RMSF
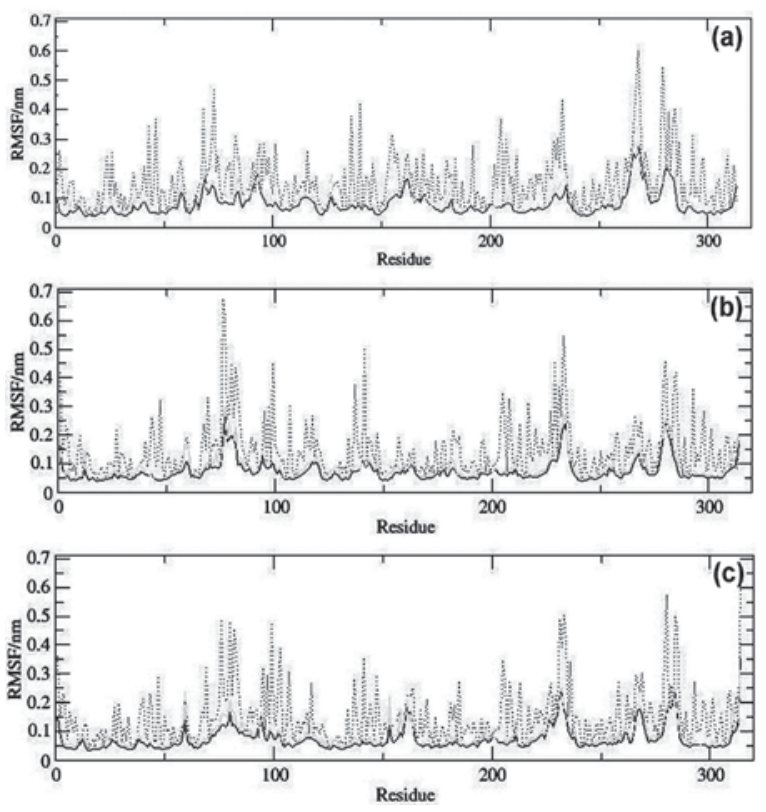

Figure 8. RMSF plots for the MD simulations, showing the deviations by residue, of: (a) $\mathrm{LdNH} / \mathrm{Ca}^{2+} / \mathrm{Compound} 1$; (b) $\mathrm{LmNH} / \mathrm{Ca}^{2+} / \mathrm{Compound} 1$; (c) $\mathrm{CfNH} / \mathrm{Ca}^{2+} / \mathrm{Compound} 1$. Black line: atoms of the backbone; Dotted line: side chain; Gray line: side chain plus backbone (total).

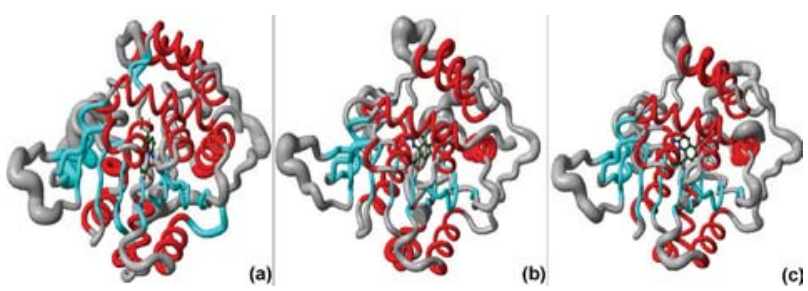

Figure 9. Qualitative illustrations of RMSF for the MD simulations of: (a) $\mathrm{LdNH} / \mathrm{Ca}^{2+} / \mathrm{Compound} 1$; (b) $\mathrm{LmNH} / \mathrm{Ca}^{2+} / \mathrm{Compound} 1$; (c) $\mathrm{CfNH} / \mathrm{Ca}^{2+}$ / Compound 1. $\mathrm{Ca}^{2+}$ ions are omitted in draws. Red tubes correspond to $\alpha-$ helix; Blue tubes correspond to $\beta$-sheets and Light gray tubes correspond to loops. The picture was generated with the Molmol software. ${ }^{56}$

for the $\mathrm{NH} / \mathrm{Ca}^{2+} / \mathrm{Compound} 1$ systems. Analyzing Figures 8 and 9 there can be determined the most mobile regions along the MD simulations as the regions with major values of RMSF and major thickness of the tubes in the tube representation. These regions correspond to the residues near the two terminus of each monomer and to the loops regions. On the other hand, the residues at the active site regions, as well as those at the $\alpha$-helix and $\beta$-sheet regions, present lower RMSF values, revealing to be the most stable regions of the system. Along the MD simulations, very few fluctuations exceeded $0.3 \mathrm{~nm}$ and even less fluctuations overpassed $0.6 \mathrm{~nm}$.

Dynamics behavior of the designed inhibitors in the active sites of LdNH, LmNH and CfNH

In order to analyze and compare the dynamics behavior of each compound inside the active sites of the enzymes 
along the MD simulations, we extracted one frame every 20 ps of simulation, totalizing 100 frames for each system. To make possible the visualization we selected, in each frame, only some of those residues directly involved in the interactions with compounds 1 and 2. The frames in Figures 10, 11 and 12 show that the two proposed compounds stay tightly bound to the active sites of all the enzymes along the whole MD simulations. The same is not observed for pAPIR, which is expelled from the active sites of $\mathrm{LdNH}$ and $\mathrm{LmNH}$. The dynamics of pAPIR inside the active site of CfNH shows that this compound is not expelled from the active site only because, differently from $\mathrm{LdNH}$ and $\mathrm{LmNH}$, the active site entrance of this enzyme is narrowed by loops L1 and L2 and also, by the side chain of Arg233 that stays at the entrance. This dynamics behavior of pAPIR probably happens because, not having substitutions on its aromatic base portion, it does not interact with the residues in the hydrophobic pocket, counting only with the interactions of the ribose portion to be stabilized inside the active site. Also, this observation corroborates the results of Milles et al. ${ }^{55}$ showing that pAPIR is a weaker inhibitor of $\mathrm{NH}$ when compared to inhibitors with substitutions on the aromatic base portion and could explain the fact that there are not any other crystallographic structures of a NH in complex with pAPIR than that with CfNH.

The fact that our proposed compounds remain tightly bound to the active sites of all the enzymes along the whole MD simulations also confirms the results of Milles et al. ${ }^{55}$ showing that the best $\mathrm{NH}$ inhibitors are the ones with substitutions on the aromatic base portion. This result also suggests that the proposed inhibitors have a good potential to become candidates for the strong inhibition of non-specific nucleoside hydrolases.

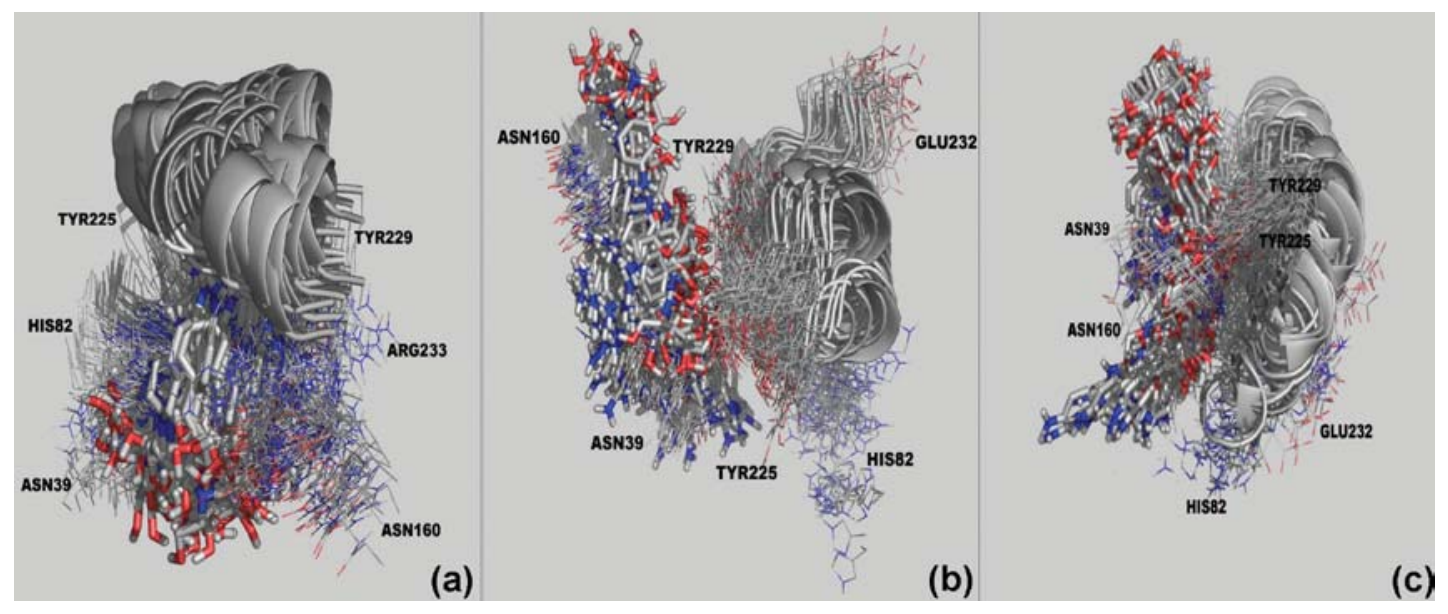

Figure 10. Dynamic Behavior of pAPIR inside the active sites of CfNH (a), LmNH (b) and LdNH (c) along the 2,000 ps of MD simulations. The picture was generated with the Pymol software. ${ }^{57}$

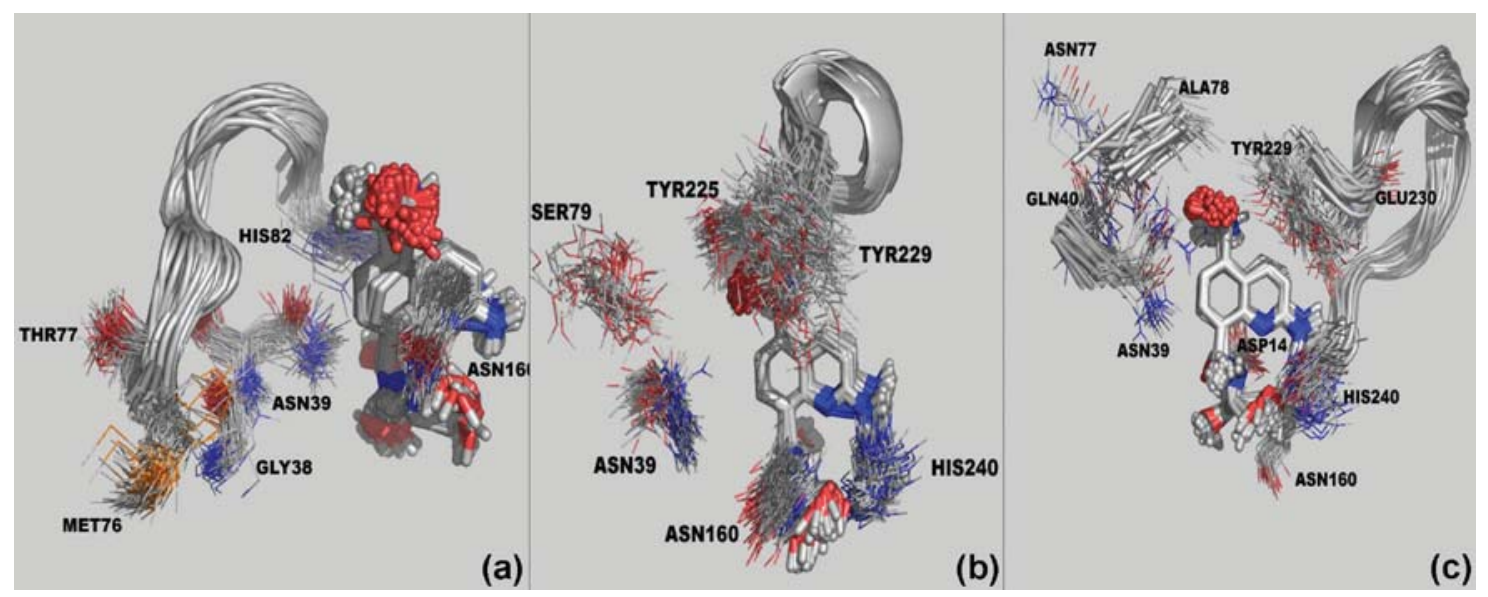

Figure 11. Dynamic Behavior of compound 1 inside the active sites of CfNH (a), LmNH (b) and LdNH (c) along the 2,000 ps of MD simulations. The picture was generated with the Pymol software. ${ }^{57}$ 

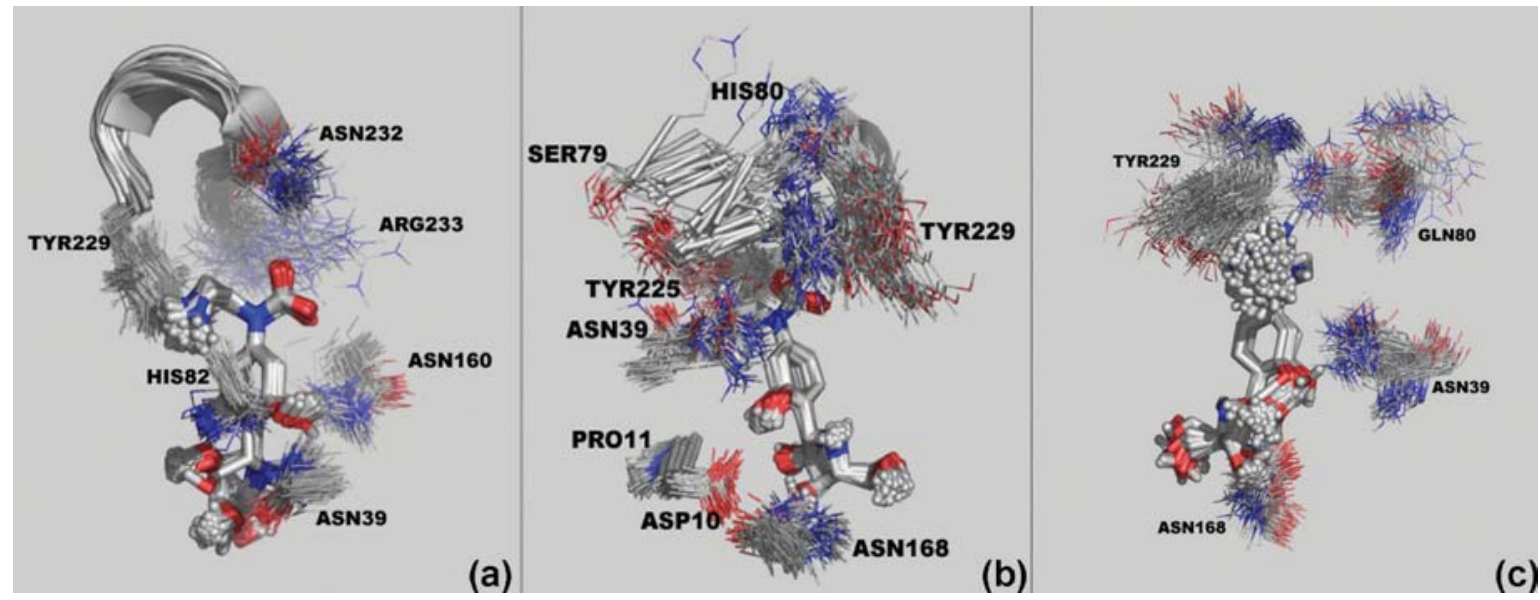

Figure 12. Dynamic behavior of compound 2 inside the active sites of CfNH (a), LmNH (b) and LdNH (c) along the 2,000 ps of MD simulations. The picture was generated with the Pymol software. ${ }^{57}$

\section{Conclusions}

In this work we have used homology modeling to propose the first 3D structure for the nucleoside hydrolase of Leishmania donovani (LdNH). Analysis of the interactions of the known NH inhibitor pAPIR with the active sites of this model and of nucleoside hydrolase from Leishmania major $(\mathrm{LmNH})$, which were based on the interactions of pAPIR co-crystallized with the nucleoside hydrolase from Crithidia fasciculata (CfNH), pointed to the hydrophobic pocket residues: Asn39, His82, Asn160, Tyr225, Tyr229 and Glu232 (Arg233 in $\mathrm{CfNH}$ ) as potential sites for enzyme-inhibitor interactions. Using that information we proposed two potential inhibitors for those enzymes, which structures were based on modifications of the aromatic base portion of pAPIR, in order to explore the potential interactions with the hydrophobic pocket. The proposed inhibitors and pAPIR were evaluated using MD simulations of the complexes formed by the docked compounds at the active sites of the enzymes. The results showed that our proposed compounds stay tightly bound to the active sites of all the enzymes along the whole MD simulations while pAPIR is expelled out of the active sites of $\mathrm{LmNH}$ and LdNH. It was found that pAPIR remains inside the active site of $\mathrm{CfNH}$ only because the narrower entrance and the presence of the side chain of $\operatorname{Arg} 233$ in this active site. The interaction of the proposed inhibitors with those residues, which are located in the hydrophobic pocket of the enzymes and are quite close to the aromatic base portion of pAPIR, explain the greater dynamics stability of their complexes with the three enzymes when compared to pAPIR. Interactions with such residues also explain the better inhibition of $\mathrm{NH}$ by pAPIR analogues with substitutions on the aromatic base portion already described experimentally in literature..$^{21,55}$
Efforts are now being carried out in our laboratory in order to propose other analogues of pAPIR as more efficient potential inhibitors, and to synthesize compounds 1 and 2 for LdNH inhibition studies and biological activity tests.

\section{Acknowledgments}

The authors wish to thank the Brazilian financial agencies CNPq, FAPERJ and CAPES, and the Millennium Institute for Structural Biology in Biomedicine and Biotechnology for financial support.

\section{References}

1. htpp://www.who.int/mediacentre/factsheets/fs116/em, accessed in January 2007.

2. Berman, J. D.; Clin. Infect. Dis. 1997, 24, 684.

3. Neves, D. P.; Melo, A. L.; Genaro, O.; Linardi, P. M; Parasitologia Humana, 10 ${ }^{\text {th }}$ ed., Editora Atheneu: São Paulo, 2000.

4. Rey, L.; Parasitologia. Parasitos e Doenças Parasitárias do Homem nas Américas e na África, $3^{\text {rd }}$ ed., Editora Guanabara Koogan: Rio de Janeiro, 2001.

5. Dole, V. S.; Raj, V. S.; Ghosh, A.; Madhubala, R. P.; Myler, J.; Stuart, K. D.; Vaccine 2000, 19, 423.

6. Abath, F. G. C.; Montenegro, S. M. L.; Gomes, Y. M.; Acta Tropica 1998, 71, 237.

7. Nogueira, F. S.; Moreira, M. A.; Borja-Cabrera, G. P.; Santos, F. N.; Menz, I.; Parra, L. E.; Xu, Z.; Chu, H. J.; Palatnik de Sousa, C. B.; Luvizoto, M. C.; Vaccine 2005, 23, 4805.

8. Rath, S.; Trivelin, L. A.; Imbrunito, T. R.; Tomazela, D. M.; Jesús, M. N.; Marzal, P. C.; Andrade Jr., H. F.; Tempone, A. G.; Quim. Nova 2003, 26, 550.

9. Frézard, F.; Schettini, D.; Rocha, O. G. F.; Demicheli, C.; Quim. Nova 2005, 28, 511. 
10. Remme, J. H. F.; Blas, E.; Chitsulo, L.; Desjeux, P. M. P.; Engers, H. D.; Kanyok, T. R.; Kayondo, J. F. K.; Kioy, D. W.; Kumaraswami, V. K.; Lasdins, J.; Nunn, P. P.; Oduola, A.; Ridley, R. G.; Toure, Y. T.; Zicker, F.; Morel, C. M.; Trends Parasitol. 2002, 18, 421 .

11. Ridley, R. G. In Drug against Parasitic Diseases; Failamb, A. H.; Rydley, R. G.; Vial, H. J., eds.; UNDP/World Bank/WHO Special Programme for Research and Training in Tropical Diseases (TDR): Geneva, 2003.

12. Parkin, D. W.; Schramm, V. L.; Biochemistry 1995, 34, 13961.

13. Gopaul, D. N.; Meyer, S. L.; Degano, M.; Sacchettini, J. C.; Schramm, V. L.; Biochemistry 1996, 35, 5963.

14. Degano, M.; Gopaul, D. N.; Scapin, G.; Schramm, V. L.; Sacchettini, J. C.; Biochemistry 1996, 35, 5971.

15. Shi, W.; Schramm, V. L.; Almo, S. C.; J. Biol. Chem. 1999, 274 , 21114.

16. Cui, L.; Rajasekariah, G. R.; Martin, S. K.; Gene 2001, 280, 153.

17. Santana, D. M.; Borja-Cabrera, G. P.; de Souza, E. P.; Sturm, N. R.; Palatnik, C. B.; Campbell, D. A; Mol. Biochem. Parasitol. 2002, 120, 315.

18. Versées, W.; Steyaert, J.; Curr. Opin. Struct. Biol. 2003, 13, 731.

19. Petersen, C.; Moller, L. B.; J. Biol. Chem. 2001, 276, 884.

20. Ogawa, J.; Takeda, S.; Xie, S-X.; Hatanaka, H.; Ashikari, T.; Amachi, T.; Shimizu, S.; Appl. Environ. Microbiol. 2001, 67, 1783.

21. Kurtz, J-E.; Exinger, F.; Erbs, P.; Jund, R.; Curr. Genet. 2002, 41, 132.

22. Pelle, R.; Schramm,V. L.; Parkin, D. W.; J. Biol. Chem. 2003, 273, 2118.

23. Ribeiro, J. M.; Valenzuela, J. G.; Insect Biochem. Mol. Biol. 2003, 33, 13.

24. Murzin, A. G.; Brenner, S. E.; Hubbard, T.; Chothia, C.; J. Mol. Biol. 1995, 247, 536.

25. Orengo, C. A.; Michie, A. D.; Jones, S.; Jones, D. T.; Swindells, M. B.; Thornton, J. M.; Structure 1997, 5, 1093.

26. Versées, W.; Decanniere, K.; Pellé, R.; Depoorter, J.; Brosens, E.; Parkin, D. W.; Steyaert, J.; J. Mol. Biol. 2001, 307, 1363.

27. Degano, M.; Almo, S. C.; Sachettini, J. C.; Schramm, V. L.; Biochemistry 1998, 37; 6277.

28. Versées, W.; Decanniere, K.; Van Holsbeke, E.; Devroede, N.; Steyaert, J.; J. Biol. Chem. 2002, 277, 15938.

29. Parkin, D. W.; Horenstein, B. A.; Abdulah, D. R.; Estupiñán, B.; Schramm, V. L.; J. Biol. Chem. 1991, 266, 20658.

30. Parkin, D. W.; J. Biol. Chem. 1996, 271, 21713.

31. Estupinan, B.; Schramm, V. L.; J. Biol. Chem. 1994, 269, 23068.

32. Mazzella, L. J.; Parkin, D. W.; Tyler, P. C.; Furneaux, R. H.; Schramm, V. L.; J. Am. Chem. Soc. 1996, 118, 2111.

33. Parkin, D. W.; Limberg, G.; Tyler, P. C.; Furneaux, R. H.; Chen, X.-Y.; Schramm, V. L.; Biochemistry 1997, 36, 3528.

34. Berman, H. M.; Westbrook, J.; Feng, Z.; Gilliland, G.; Bhat, T. N.; Weissig, H.; Shindyalov, I. N.; Bourne, P. E.; Nucleic Acids Res. 2000, 28, 235.
35. Altschul, S. F.; Gish, W.; Miller, W.; Myers, E. W.; Lipman, D. J.; J. Mol. Biol. 1990, 215, 403.

36. Altschul, S. F.; Madden, T. L.; Schaffer, A. A.; Zhang, J.; Zhang, Z.; Mille, W.; Lipman, D.; Nucleic Acids Res. 1997, 25, 3389.

37. Guex, N.; Peitsch, M. C.; Electrophoresis 1997, 18, 2714.

38. Peitsch, M. C.; Biotechnology 1995, 13, 656.

39. Peitsch, M. C.; Biochem. Soc. Trans. 1996, 24, 274.

40. Frisch, M.J.; Trucks, G.W.; Schlegel, H.B.; Scuseria, G.E.; Robb, M.A.; Cheeseman, J.R.; Zakrewski, V.G.; Montgomery, J.A.; Stratman, R.E.; Vurant, J.C.; Dapprich, S.; Millam, J.M.; Daniels, A.D.; Kudin, K.N.; Strain, M.C.; Farkas, O.; Tomasi, J.; Barone, V.; Cossi, M.; Cammi, R.; Mennuci, B.; Pomelli, C.; Adamo, C.; Clifford, S.; Ochterski, J.; Petersson, G.A.; Ayala, P.Y.; Cui, Q.; Morokuma, K.; Malick, D.K.; Rabuch, A.D.; Raghavachari, K.; Foresman, J.B.; Cioslowshi, J.; Ortiz, J.V.; Stefanov, B.B.; Liu, G.; Liashenko, A.; Piskorz, P.; Komaromi, I.; Gomperts, R.; Martin, R.L.; Foz, D.J.; AlLaham, T.M.; Peng, C.Y.; Nanayakkara, A.; Gonzalez, C.; Challacombe, M.; Gill, P.M.W.; Jonson, B.; Chen, W.; Wong, M.W.; Andres, J. L.; Gonzalez, C.; Head-Gordon, M.; Reploge, E.S.; Pople, J.A.; Gaussian 98, Revison A.6, Gaussian, Inc.: Pittsburg, PA, 1998.

41. Lindahl, E.; Hess, B.; Van der Spoel, D.; J. Mol. Mod. 2001, 7, 306.

42. Berendsen, H. J. C.; Van der Spoel, D.; Van Drunen, R.; Comput. Phys. Commun. 1995, 91, 43.

43. Schuettelkopf, A. W.; van Aalten, D. M. F.; Acta Crystallogr., Sect. D: Biol. Crystallogr. 2004, 1355.

44. Jorgenson, W. L.; Tyrado-Reeves, J.; J. Am. Chem. Soc. 1988, 110, 1657.

45. http://biotech.ebi.ac.uk/cgi-bin/sendquery (accessed in May 2006).

46. Pontius, J.; Richelle, J.; Wodak, S. J.; J. Mol. Biol. 1996, 264, 121.

47. Laskowski, R. A.; Macarthur, M. W.; Moss, D. S.; Thornton, J. M.; J. Appl. Crystallogr. 1993, 26, 283.

48. Vriend, G. J.; J. Mol. Graph. 1990, 8, 52.

49. Bowie, J. U.; Luthy, R.; Eisenberg, D.; Science 1991, 253, 164.

50. Luthy, R.; Bowie, J. U.; Eisenberg, D.; Nature 1992, 356, 83.

51. http://nihserver.mbi.ucla.edu/Verify_3D/, accessed in May 2007.

52. Sippl, M. J.; Proteins 1993, 17, 355.

53. Ramachandran, G. N.; Sasisekharan, V.; Adv. Prot. Chem. 1968, $23,283$.

54. Wiederstein, M.; Lackner, P.; Kienberger, F.; Evolutionary Methods in Biotechnology, Wiley-VCH: Weinheim, 2004.

55. Miles, R.W.; Tyler, P. C.; Evans, G. B.; Furneaux, R. H.; Parkin D. W.; Schramm, V. L.; Biochemistry 1999, 38, 13147.

56. Koradi, R.; Billeter, M.; Wuthrich, K.; J. Mol. Graph. 1996, 14, 51.

57. DeLano, W. L.; Bromberg, S. PyMOL User's Guide, DeLano Scientific LLC: San Francisco-CA, 2004.

Received: March 13, 2007 Published on the web: January 22, 2008 